\title{
JONES, DECHOW AND KASZNIK MODELS SIGNIFICANCE IN THE ROMANIAN ECONOMIC ENVIRONMENT
}

\author{
Dumitru Matiş $\left.{ }^{1 *}\right)$ \\ Alina Beattrice Vladu ${ }^{2(* *)}$ \\ Laura Negrea ${ }^{3}$ \\ Lucia Sucala ${ }^{4}$
}

\begin{abstract}
This study intends to be a first step into an attempt of measuring the earnings management using an econometric model valid for the Romanian specificities by trying to establish the level of significance of three acknowledged econometric models: Jones (1991), Dechow et al. (1995) and Kasznik (1999) on Romanian economic environment.

Given the above mentioned premises, the study was conducted using the Romanian listed companies (active on the Bucharest Stock Exchange) selected by a main criteria: discrepancy between reported cash flow and reported net income. Our analyses lead us to the conclusion related to the above mentioned issues that Jones model was found to be significant for Romanian economic environment in terms of applicability unlike Dechow and Kasznik models, thus it may be further developed and applied to an extended database.
\end{abstract}

Key words:earnings management, manipulation, cash flow

JEL codes: $M 41$

\section{Introduction}

Among many research topics in accounting, none is perhaps more provocative than earnings management. Why is that? We believe it's because the topic explicitly involves potential wrongdoing, sometimes conflict, hard to detect and in a sense those issues involves a lot of mystery related to the potential victims of earnings management - investors, bankers, regulators, unions, suppliers, customers, competitors.

The aim of this paper is to make the first step in investigating whether in the Romanian economic context we can find evidences of earnings management. In order to do that we have selected 101 listed companies on Bucharest Stock Exchange, from tier I and II, for the years 2007 and 2008 based on the fact that we could find complete data for those particular years.

The basic idea of our study is that when a business reports profits without generating cash we must get a little suspicious. We approached the vital importance of cash flow statement that can be used as a real aid in providing warning signs determining further analysis to discover if the financial statements were developed according to the true and fair view concept.

\footnotetext{
${ }^{1}$ Full Professor, PhD, Babes-Bolyai University Cluj-Napoca, Faculty of Economics and Business Administration, dumitru.matis@econ.ubbcluj.ro

2 PhD Student, Babes-Bolyai University Cluj-Napoca, Faculty of Economics and Business Administration, beattrice.vladu@econ.ubbcluj.ro

3 PhD Student, Babes-Bolyai University Cluj-Napoca, Faculty of Economics and Business Administration, emaillaura007@yahoo.com

${ }^{4}$ Associate Professor, Phd, Babes-Bolyai University Cluj-Napoca, Faculty of Economics and Business Administration, lucia.sucala@econ.ubbcluj.ro
} 
We have than tried to establish the level of significance of three acknowledged models: Jones (1991), Dechow et al. (1995) and Kasznik (1999) if applied in the Romanian economic environment.

Given the above mentioned premises, the study was conducted using the Romanian listed companies (active on the Bucharest Stock Exchange) selected by a main criteria: discrepancy between reported cash flow and reported net income.

As regarding to the previous literature that approached this topic we can assert that is considered to be consistent, fact that underlies the importance and interest on manipulative behaviour.

Earnings management concerns managers using their discretion over accounting accruals and accounting choices, presumably for a private or personal purpose. However, the law requires management to make judgments and estimates in order to provide periodical financial reports and not infrequently certain forms of earnings management, such as income smoothing, are hard to distinguish from appropriate accounting choices (Dechow and Skinner, 2000). The critical issue in the literature in this respect is considered to be the act of distinguishing regular accrual accounting from earnings management. The main reason for engaging in an manipulative behaviour is related to the stock market and further to the increase value of a company. Hence, earnings management may also be used as a strategic tool by managers of companies.

Even if the motivations for engaging in earnings management are discussed in the literature and also the effects of such manipulative tools are assessed, the detection is considered to be difficult since the designs used in the literature compressed indirect measures (e.g. indicators that measure the possible consequences of earnings management). In this regard the main problem appears to be their representativeness of the unit and the fact that those measures may be caused by multiple reasons besides earning management.

A reliable way to detect earnings management is to compare a company's reported operating profit with the cash flow of the year or better with operational cash flow.

In our study we used this particular method in order to select from 101 listed companies in the Bucharest Stock Exchange those who presented positive net income and negative cash flow of the year respectively negative operational cash flow.

If the net income is healthy but there is a net cash flow which in negative then the company is making use of creative accounting as pointed Schilit (2002) and Smith (1996).

If a company has an ever increasing net income there cannot be a net cash outflow all the time, hence the company is certainly manipulating their profits through the use of book entries. The companies cannot create cash but they enhance their profits.

Our future research, starting with this study, completes the Romanian literature by providing useful information about measuring the earnings management using an econometric model (as far as we know this is the first attempt of its kind in Romania). As we pointed before this study is one of the first to examine the quality of the financial statements of Romanian listed companies.

This study is meant to be a first step, as it tries to present three econometric models, acknowledged by related literature, involved in accruals determination, in order to test their significance for Romanian market.

While earnings management receives a lot of attention in the academic press and not only, regulators and practitioners seem to believe that earnings management is both pervasive and problematic.

Academics usually make general statements about earnings management by examining large samples of firms, by using statistical definitions of earnings management that may not be very powerful in identifying earnings management and not being able to combat this phenomena which become more widen every day (see for instance Kang and Sivaramankrishnan, 1995; Dechow et al., 1995; Guay et al., 1996; Bernard and Skinner, 1996; Healy and Wahlen, 1999; Dechow and Skinner, 2000; McNichols, 2000; Kothari, 2001; Kothari et al., 2005). 


\section{Relevant literature and hypothesis development}

Many of the previous accounting studies examined the different motivations of earnings management and the factors that induce managers' incentives to manage reported earnings. We have selected a few motivations as following:

- Reported income is decreased or increased so as to reduce its volatility (Herrmann and Inoue, 1996; Ball, Kothari and Robin, 2000),

- Avoided of losses (Burgstahler and Dichev, 1997; Degeorge, Patel and Zeckhauser 1999; Burgstahler and Eames, 2003),

- Improve the terms of transactions (Bowen, DuCharme and Shores, 1995),

- Trying to convince debt holders that earnings have lower volatility and hence represent a reduced risk (Kirschenheiter and Melumad, 2002),

- Satisfy the debt covenants (Healy and Palepu, 1990; Defond and Jiambalvo, 1994; DeAngelo and Skinner, 1994; Sweeney, 1994),

- Reduce the political costs (Cahan, 1992; Jones 1991),

- Stock price motives such as stock offering (Teoh, Welch and Wong, 1998; Erickson and Wang, 1999; Shivakumar, 2000),

- Meet analyst's expectations (Burgstahle and Eames, 1998; Degeorge, Patel, and Zeckhauser, 1999; Collingwood, 2001),

- Increase owners confident towards a company that reports stable earnings and this may improve managers relations with inverstors and with employees (Hepworth, 1953),

- Increase managers compensations when earnings are increasing because they are tied to those reported earnings (Healy, 1985; Holthausen, Larker and Sloan, 1995),

- Lower the tax burden, issues regarding tax incentives (Beatty and Harris, 1998; Klassen, 1997; Lamb, Nobes, and Roberts ,1998; Ball and Shivakumar, 2004),

- Make the investors believe that the company is having a big turnaround after a difficult period (Collingwood, 2001).

As it can be seen from the motivations addressed before there are manifold reasons for managers to manage earnings. At the fundamental level, all those reasons are related to the performance of the company, seen sometimes like a real benchmark. This benchmark could be the desire to meet analysts' expectations or the desire to remain profitable in order to meet the bonus threshold.

One of the most important accounting numbers for stakeholders in an annual report is the net profit, or profit before extraordinary items. It is this number that measures the overall performance of the company over the past year. But, this profit is not only determined by the achievements and the state of the company, but it can also be influenced by discretionary adjustments in the accounting numbers by management.

In a context of information asymmetries, the manager can opportunistically manage the accounting number in order to present the results that are expected by the analysts and through their interpretations by the market. When those accounting numbers doesn't match the market expectations managers will try to avoid the negative consequences through earnings management primarily.

Earnings management is the intentional misstatement of earnings leading to bottom line numbers that would have been different in the absence of any manipulation and when we are talking about earnings management does not always have to mean upwards manipulation, does not always have to be related to changes in accounting practices, does not have to be related to the income smoothing of earnings, does not have to be illegal, moreover what managers are doing is completely legal. They are using the discretion at their disposal to present their financial results in a manner that best suits their interests. 
But before we can discuss about earnings management we have to define it which is not an easy task because there is not a single definition of earnings management in the literature but many. One of the pioneer definitions regarding earnings management belongs to professor Katherine Schipper (1989) who in "A Commentary on Earnings Management", published in Accounting Horizons (December 1989, pp. 92) stated that "by 'earnings management' "we should understand 'disclosure management' in the sense of a purposeful intervention in the external financial reporting process, with the intent of obtaining private gain (as opposed to, say, merely facilitating the neutral operation of the process)".

Since this definition is highly cited in the literature some appreciations can be made. Schipper $(1989,92)$ is regarding earnings management as a practice that can occurred in any segment of external disclosure process and as he pointed out, this complex technique seen as a whole can take various forms of manifestation. Being approached from an informational point of view, this definition asserted that earnings can be used easily to make certain decisions or judgments.

Michael R. Young in his book Accounting Irregularities and Financial Fraud: A Corporate Governance Guide (2000, p. 13) describes earnings management as embracing two types of "managed earnings" and stated that: "Now in talking about managed earnings, one has got to be careful. There are two types of managed earnings. One type is simply conducting the business of the enterprise in order to attain controlled, disciplined growth. The other type involves deliberate manipulation of the accounting in order to create the appearance of controlled, disciplined growth when, in fact, all that is happening is that accounting entries are being manipulated ".

Dechow and Skinner (2000:238) regards earnings management as legitimate practices but with management intent to deceive information users. In this respect, the managerial intent is clear, which results in a clear definition of earnings management as the authors asserted: "the intentional, deliberate, misstatement or omission of material facts, or accounting data, which is misleading and, when considered with all the information made available, would cause the reader to change or alter his or her judgment or decision".

Clikeman, Geiger and O Connell (2001) defines earnings management as a practices of making discretionary accounting choices or timing operating decisions to move reported earnings toward a desired goal while Wild et al. (2001:120) defines it as a "purposeful intervention by management in the earnings determination process, usually to satisfy selfish objectives".

Since we approached the motivations that underlie and initiates the opportunistic behaviour of the managers we can assert that most important than that what is the main effect of earnings management or management manipulations?

In the literature there is a consensus that companies in short period of time are able to "fool" the market by implementing practices of earnings management as Rutherford (2003) and Courtis (2004) documented.

For this effect to be lasting other factor has contributed to its success and in this respect the importance given to earnings treated as being one of the most important sources of public financial disclosures as long as most of the financial users consider it the most important indicator of company performance is crucial.

This particular judgement can bring a lot of trouble for the users of financial information and can maintain these ability of managers of ,fooling" the market primordial because the accruals component of earnings is being ignored like the fact that this particular component involves estimates and judgements, this flexibility for managers to select appropriate accounting method and estimation also provides opportunity for managers to manage earnings. Consequently, intentional and unintentional errors in accrual weaken the relation between current earnings and future cash flows, thereby reducing earnings quality.

Richard Sloan (1996) in his pioneering paper showed that the accrual component of earnings is less persistent and has a greater subjectivity than the cash flow component of earnings. When we 
are talking about accruals all comes done to the cash accounting versus accrual accounting. Cash accounting - revenues are recorded when cash is received from operating activities and expenses are recorded when cash payments relating to operating activities are made. On the other hand, accrual accounting - revenues are recorded when earned and expenses are recorded in the period in which they generate revenues.

The main goal of accrual accounting is to help investors assess the entity's economic performance during a period through the use of basic accounting principles such as revenue recognition and matching. Research has shown that the accrual process results in earnings that are smoother than underlying cash flows, since accruals tend to be negatively related to cash flows, and that earnings provide better information about future economic performance to investors than cash flows (Dechow, 1994) but on the other hand earnings like we said before are less persistent and has a greater subjectivity than the cash flow.

Cash flow reporting, in the form we can see today, is a relatively new concern and if we are referring to the Romanian economic context cash flow reporting is far from being implemented as it should be despite the fact that its importance is crucial for the financial information users.

Professors C.W Mulford and E.E Comiskey (2005), argue that the delay in mandating the statement of cash flows may be linked to earlier ongoing efforts to transition more completely to a full accrual, as opposed to a mixed cash and accrual, basis of accounting. The development of cash measures of performance was seen as potentially undermining the prominent role accorded to net income as a measure of financial performance.

In the last few decades many researchers and specialists have allocated time and resources to studying the many advantages of cash flow statements, their usefulness in assessing financial performance, as well as their ability of predicting future results. Pricewaterhouse Coopers Professor of Corporate Finance, Pablo Fernandez (2008) states that a company's net income is quite arbitrary figure obtained after assuming certain accounting hypotheses regarding expenses and revenues (one of several that can be obtained, depending on criteria applied). However, the ex-post cash flow is an objective measure, a single figure that is not subject to any personal criterion.

According to researchers like Dr. Sharma (2001), cash flow information contains significantly greater information content than traditional accrual information for the purposes of assessing corporate financial health. After an experimental study involving 90 business banking managers, the conclusion was that a more accurate credit and default risk assessment was achieved based on cash flow information, thus reducing cost of default.

On the other hand, specialists like R. Reider and P.B. Heyler (2003), focus on the idea that business owners, managers, shareholders and many others have become enamoured with sales and revenue increases, reported profits, earnings per share, price-earnings ratios, cost reductions, and related concepts that focus on the market capitalization of the business and its related stock price per share. At the same time, they state that such measures for financial performance have minimal significance for the business without cash. "Cash availability is the lifeblood of the organization".

As can be seen in previous examples, more and more specialists acknowledge the importance of cash flow reporting. International and national standards have been focusing on drawing the main lines for the issuance of such reports that are able to offer real and useful data related to the financial performance of the companies.

In addition, the relevance of information provided by cash flow statements as opposed to net income has been an object of many research studies in the recent period. Usually cash flow information has been considered as less of a subject for accounting manipulation than accrual data. Zhang W. (2008) states that cash flow is less subjective, as compared to accruals, so it can be regarded as a "harder" benchmark in evaluating a firm's performance. Attar A.A. and Hussain S. (2004), examine the ability of current accounting data to explain future cash flows for UK firms. They used some econometric models to verify the explanatory power of currently available data 
(earnings, cash flow and accruals) in relation to future cash flows occurring one-year-ahead, or more. They find that accruals data are affected by many factors. For example, applying different accounting policies can result in measurement variations. The conclusion states that earnings are vulnerable to management manipulation and that while current cash flow data appears to explain future cash flows better than do current earnings, the combination of cash flow and accruals data generates the greatest explanatory power.

Cheng C.S.A. and Yang S.M (2003) find that supplementary role of cash flow exists only when cash flows are moderate. Likewise, only moderate, not extreme earnings serve a supplementary role to cash flow.

Others, like Sharma and Iselin (2003) argue that considering the debate on cash flow versus accrual information, and based on behavioural experiment, the statement of cash flow was found to be of greater relevance in judgments regarding solvency. They state that cash flow information could serve as alternative information set, since it provides fewer opportunities for managerial manipulation. Even if management faithfully report the results of operations and financial performance, the presence of accruals, allocations and transitory items would render accrual financial information less relevant for solvency assessment.

Cash flow information should be crucial for the users of financial information like accrual is crucial information when trying to detect earnings management.

Accruals, is defined as the difference between Net Income and Cash from Operations. At a first pass, companies with a high level of accruals are likely to have inflated earnings more likely those companies use some creative accounting practices. However, using total accruals as a proxy for earnings management is simplistic because firms can have high accruals for reasons such as growth in sales (increase in receivables) and additions to property plant and equipment (increase in depreciation).

Many researchers in the field of financial accounting have tried to measure earnings management by disentangling accruals into discretionary accruals and non-discretionary accruals. An example of a commonly used model is the Jones model, based on a paper by Jones (1991). This particular model considers the total accruals as the dependent variable. Independent variables include controls for growth in revenues and property plant and equipment and of course receivables. Other two models used in the literature in order to measure de magnitude of earnings management are Dechow model and Kasznik model, both of them being derived from the original Jones model.

In order to detect earnings management through Romanian listed companies and in the same time working effectively by using information provided by the cash flow statement we develop Hypothesis I. The main idea is that when the gap between Net Income and Cash Flow from Operations is increasing the company might be "fiddling around" with accruals. If those models are relevant they can be used in the future study to detect earnings management.

So, Hypothesis I, II and III are developed as following:

Hypothesis I: Jones, model is relevant for the Romanian economic environment,

Hypothesis II: Dechow model is relevant for the Romanian economic environment,

Hypothesis III: Kaszkik model is relevant for the Romanian economic environment.

\section{Experimental design}

Earlier studies regarding the detection and measurement of the earnings management widely used either time-series data (Dechow, Sloan, and Sweeny, 1995; Guay, Kothari and Watts, 1996; Jones, 1991) or crossection data (Bartov, Gul and Tsui, 2001; Becker, DeFond, Jiambalvo and Subramanyam, 1998; DeFond and Subramanyam, 1998; Peasnell, Pope and Young, 2000). The time-series studies assume temporal stationarity of parameter estimates, while the cross-sectional studies assume homogeneity across firms in the same industry (Larker and Richardson, 2004).

The difficulty in evaluating the power of metrics for detecting earnings management lies in the fact that earnings management is not directly observable. One way to circumvent this problem is 
to choose a setting where researchers have strong priors that earnings management is likely to occur.

Based on the literature, we have strong priors that earnings management is likely to occur in those companies that reported positive net income two years consecutive and in the same time negative cash flow.

The study presented is intended to be just a first step, in detecting potential earnings management for Romanian companies.

In this respect, we have selected three models presented below, each of them concentrating on different factors that are used in estimating total accruals.

We have tested the models on Romanian companies selected as mentioned below, trying to detect their significance, taking as samples as we said before those companies that reported positive income two years consecutive and in the same time negative cash flow.

We applied those three models on this particular sample of companies.

Also, we have made the necessary analysis in order to discover the relevant influence of the factors involved in the models, to the value of total accruals.

This study used all listed companies from Romania, listed as we said before on Bucharest Stock Exchange, selecting all the companies from tier I and respectively II.

Period selected was year 2007 and 2008 and related to that the financial statements. Details of sample firms are as follow:

- Number of companies that we have selected from tier I and II is 101.

- Fewer companies that presented negative net income in years 2007 and 2008: 43

- Less companies with positive cash flow in years 2007 and 2008: 22

- Number of companies used as sample 36.

- The company has fiscal- year end of $12 / 31$.

- The company has available annual accounting data from published on Bucharest Stock Exchange as earnings, receivables, liabilities, total assets and other information required for estimation of non-discretionary accruals (discretionary accruals).

Banks and financial institution are excluded from the sample because the distinguished characteristics of accruals for this type of industry differ significantly with accruals of other industry.

In order to be able to test the selected models we begin with total accruals as we said before and we defined as the change in non-cash current assets minus change in current liabilities excluding the current long term debt minus depreciation and respectively the amortization. Consistent with existing research we scaled total accruals by lagged total assets.

Having in mind that accounting manipulation is far less expensive than real earnings management, it is easily assumed they tend to become an important issue in the management of earnings, one that was subject to several studies.

Accruals management was considered a favourite instrument, as it is more difficult to detect. There can be found, according to Hribar and Collins (2002), two ways of measuring accruals, depending either on the balance sheet or on the cash flow statement of a company. 'Despite the availability of accurate accruals data in the statement of cash flow since 1988, the majority of these studies use an indirect balance sheet approach to calculate accruals' is one of the observations of Hribar and Collins (2002).

Following Collins and Hribar (2001), we used cash flow statement items to compute total accruals (ACCR) as follows:

\section{ACCRt $=$ EBEIt - CFOt}

\section{Where:}

- EBEIt is income before extraordinary items,

- CFOt is cash flow from operations in year $t$. 
Consistent with previous literature we used consecutive balance sheet data items to compute total accruals (ACCR) in cases where we couldn't calculate total accruals using the previous formula. In those particular cases we used as follows (Healy 1985 and Jones 1991):

Where:

$$
\text { ACCRt }=\Delta \text { CAt }-\Delta \text { Casht }-\Delta C L t+\Delta \text { STDt }-\Delta \text { EPt }
$$

- $\quad \Delta \mathrm{CA}$ is change in current assets,

- $\quad \Delta$ Cash is change in cash/cash equivalents,

- $\quad \Delta \mathrm{CL}$ is change in current liabilities,

- $\quad \triangle$ STD is change in debt included in current liabilities or change in short-term notes and current portion of long-term debt,

- $\quad \Delta \mathrm{EP}$ is depreciation and amortization expense.

As far as studied literature shows, the Jones (1991) and the modified Jones model are the most popular models. Based on studies performed by Healy (1985) and DeAngelo (1986), they tend to be basis for many other models, trying to develop previous results.

As mentioned before, relevant literature in this area begins with Healy (1985) and DeAngelo (1986), who used total accruals and change in total accruals, respectively, as measures of management's discretion over earnings.

We focused in determining the significance of three appreciated models, applied on the selected Romanian companies. We mention also that all variables are deflated by the opening value of total assets.

\section{JONES MODEL (1991):}

$$
\text { ACCRit }=\alpha 0+\alpha 1 \Delta R E V i t+\alpha 2 \text { PPEit }+ \text { eit }
$$

Where:

- ACCRit is total accrual, measured by the difference of income before extraordinary item and cash flow from operating activities,

- $\quad \triangle$ REVit is change in revenue, measured by change in Salesit relative to Sales it-1,

- PPEit is gross value of property, plant and equipment in year $t$.

> DECHOW MODEL (1995) - known as MODIFIED JONES MODEL:

Where:

$$
\text { ACCRit }=\alpha 0+\alpha 1(\Delta R E V i t-\Delta R E C i t)+\alpha 2 \text { PPEit }+ \text { eit }
$$

- ACCRit is total accrual,

- $\triangle \mathrm{REV}$ it is change in revenue, measured by change in Sales it relative to Sales it-1,

- $\quad \triangle$ RECit is change in net account receivable in year $t$ relative to year $\mathrm{t}-1$,

- PPEit is gross value of property, plant and equipment in year $t$.

\section{KASZNIK MODEL (1999) - known as CFO MODIFIED JONES MODEL:}

$$
\text { ACCRit }=\alpha 0+\alpha 1(\Delta R E V i t-\Delta R E C i t)+\alpha 2 \text { PPEit }+\alpha 3 \Delta C F O i t+\text { eit }
$$

Where:

- ACCRit is total accrual,

- $\quad \triangle$ REVit is change in revenue, measured by change in Salesit relative to Sales it-1,

- $\quad \triangle$ RECit is change in net account receivable in year $t$ relative to year $t-1$,

- PPEit is gross value of property, plant and equipment in year $t$,

- $\quad \triangle$ CFOit is change in operating cash flow in year $t$ relative to year $\mathrm{t}-1$. 
By considering the analyzed period as 2008 , we have determined all the factors involved in above mentioned three models, trying to test to what extent the models are significant when applied on Romanian companies, trying also to follow the degree of influence of the components involved in the computing process.

The dependent variable was considered the value of Total Accruals (scaled by Assets at 2007 yearend) while all the other components were analyzed as potential influencer factors.

\section{Findings}

For the analysis of our data we used SPSS 16.0 software.

As we can see from Table No. 1 were we presented the descriptive statistics for the sample companies (sample data consist of 36 companies) the Jones model is a significant model. Also the standard deviation of the sample is not high, decreasing the possibility that the data are not following normal distribution.

\section{Descriptive statistics}

\begin{tabular}{|c|c|c|c|}
\hline Variables & Mean & Std.deviation & $\mathbf{N}$ \\
\hline ACCR & -.0180 & .12195 & 36 \\
\hline$\Delta$ REV & .136430 & .3333616 & 36 \\
\hline PPE & .5339 & .24990 & 36 \\
\hline
\end{tabular}

Source: Projection by the authors

The descriptive statistics show us that the values are rather homogeneous.

Analysing the correlation between each of the independent variables and the total accruals (which is the dependent variable abbreviated by ACCR in our analysis using SPSS 16.0 Software); we discover that by following the Jones model, the variation of revenues is the most relevant factor. As we can see from Pearson Correlation Table No. 2 the independent variable abbreviated by REV ( $\triangle \mathrm{REVit}$ is change in revenue, measured by change in Sales it relative to Sales it-1) is positively associated with the dependent variable ACCR (total accruals) and negatively associated with the other independent variable abbreviated PPE (PPEit is gross value of property, plant and equipment in year $\mathrm{t}$ ). In our study year $\mathrm{t}$ is year 2008 .

Table No. 2

Pearson Correlation

\begin{tabular}{|c|c|c|c|}
\hline Variable & ACCR & DREV & PPE \\
\hline ACCR & 1.000 & .359 & -.280 \\
\hline$\Delta$ REV & .359 & 1.000 & -.292 \\
\hline PPE & -.280 & -.292 & 1.000 \\
\hline
\end{tabular}

Source: Projection by the authors

For further verification Ordinary least square (OLS) test has been performed, the results of are shown in the following table:

Table No. 3

Model summary

\begin{tabular}{|c|c|c|c|c|}
\hline Model & t-test & R-square & F-statistics & $\begin{array}{c}\text { Significance of } \\
\text { F-statistics }\end{array}$ \\
\hline & .335 & .163 & 3.205 & $.053^{\mathrm{a}}$ \\
\hline
\end{tabular}

Source: Projection by the authors 
By applying the Jones Model, according to ANOVA test, the significance level of the model is approximately 0.05 , thus we can accept there's an influence between the studied data groups, to be further developed on a more comprising database, and we can assess the model as significant also for Romanian market.

By applying Dechow model we obtained the following results presented in Table No. 4:

Descriptive Statistics

\begin{tabular}{|c|c|c|c|}
\hline Variables & Mean & Std.deviation & N \\
\hline ACCR & -.018026 & .1219508 & 36 \\
\hline PPE & .533863 & .2499009 & 36 \\
\hline$\triangle$ REVREC & .146642 & .3499851 & 36 \\
\hline
\end{tabular}

Source: Projection by the authors

In terms of Pearson Correlation (Table No. 5) the independent variable REVREC ( $\triangle$ REVit which is change in revenue, measured by change in Sales it relative to Sales it-1 minus $\triangle$ RECit which is change in net account receivable in year t relative to year t-1) is positively associated with the dependent variable ACCR while the independent variable PPE is negatively associated with the dependent variable.

Table No. 5

\section{Pearson Correlation}

\begin{tabular}{|c|c|c|c|}
\hline Variable & ACCR & PPE & DREVREC \\
\hline ACCR & 1.000 & -.280 & .336 \\
\hline PPE & -.280 & 1.000 & -.319 \\
\hline$\Delta$ REVREC & .336 & -.319 & 1.000 \\
\hline
\end{tabular}

Source: Projection by the authors

The results obtained by applying ANOVA test are presented in Table No. 6.

Table No. 6

Model Summary

\begin{tabular}{|c|c|c|c|c|}
\hline Model & t-test & R-square & F-statistics & $\begin{array}{c}\text { Significance of } \\
\text { F-statistics }\end{array}$ \\
\hline & .353 & .146 & 2.831 & $.073^{\mathrm{a}}$ \\
\hline
\end{tabular}

Source: Projection by the authors

As we can see the significance of the Dechow model is at a low level.

By applying Kasznik model we can see that the independent variables PPE and CFO ( $\triangle$ CFOit is change in operating cash flow in year t relative to year t-1) are negatively associated with the dependent variable ACCR while the independent variable REVREC is positively associated with the dependent variable ACCR. We can see the results in Table No.

Table No. 7

Pearson Correlation

\begin{tabular}{|c|c|c|c|c|}
\hline Variable & ACCR & PPE & $\triangle \mathrm{CFO}$ & $\triangle$ REVREC \\
\hline ACCR & 1.000 & -.280 & -.082 & .336 \\
\hline PPE & -.280 & 1.000 & .253 & -.319 \\
\hline$\triangle \mathrm{CFO}$ & -.082 & .253 & 1.000 & .191 \\
\hline$\triangle$ REVREC & .336 & -.319 & .191 & 1.000 \\
\hline
\end{tabular}


Testing ANOVA we obtained the following results presented in Table No. 8:

Table No. 8

Model Summary

\begin{tabular}{|c|c|c|c|c|}
\hline Model & t-test & R-square & F-statistics & $\begin{array}{c}\text { Significance of } \\
\text { F-statistics }\end{array}$ \\
\hline & .353 & .155 & 1.956 & $.140^{\mathrm{a}}$ \\
\hline
\end{tabular}

Source: Projection by the authors

In all the three models the independent variable REV or REVREC is positively associated with the dependent variable ACCR while as we can observe by studying the descriptive statistics the PPE or CFO is negatively associated with the dependent variable. Still the correlation does not seem very intense, thus further study is needed. As we said the PPE indicator shows a negative correlation with the total accruals (ACCR), which was expected, as property, plant and equipment are related to an income-decreasing accrual.

Apparently though, the variation of revenues has approximately the same influence, when used on its own, as well as when it is deflated with the evolution of receivables.

As far as the other two models Dechow and Kasznik (please see the ANOVA results from Table No. 6 and Table No. 8), their significance was of low level, thus we intend to further develop the research, by using the Jones model, applied to a large panel of Romanian companies, divided into groups based on firms' specific parameters.

According with the results that we obtained we can declare that the Hypothesis I is being validated while Hypothesis II and III are being rejected.

\section{Conclusions}

Accruals management included in the sphere of earnings management is difficult to detect. Thus analyzing other reports like the cash flow statement it may occure sigs of accounting manipulation. Managers are various reasons, motivations or incentives into using manipulative techniques like: avoiding losses reduce earnings volatility, increase owners confidence and others.

Almost all studies define earnings management as related to the clear intention of management to alter the decisions based on the financial statements.

In order to detect those particular manipulations cash flow reporting has a crucial relevance for financial information users. Today, more and more specialists acknowledge the importance of cash flow reporting on evaluating a company's performance. The high discrepancy between high net income and negative cash flow may be a warning sign. On the other hand accruals can be essential for detecting earnings management.

In our study we used those computed direction in order to test the significance of Jones, Dechow and Kasznik models in the Romanian economic environment.

Earnings management is difficult to quantify, as it cannot be observed directly.

Using observable signals like discrepancy between the low (even negative) cash flow and high net income are helping end-users rise up questions on potential earnings management.

Hypothesis I stating that Jones Model is relevant for the Romanian market has been tested and the assumption is valid, that means that the Hypothesis is validated and we are going to use Jones Model in our further developments.

In terms of Hypothesis II and III, that the Dechow model respectively the Kasznik Model, are relevant for the Romanian economic environment, we found that those models are not significant which means that the hypothesis stated above are rejected.

Surprising is that both Dechow and Kasznik models were found to be not significant for the Romanian economic environment, surprising as we said considering the fact that both models are modified versions of the Jones model. 


\section{Limitations of the present study and scope for future research}

Our study was conducted using a relatively small sample of 36 companies form tier I and II, companies listed on Bucharest Stock Exchange, the testing being performed for only 2007 and 2008 (dates from 2007 were used in calculating the total accruals). This is a limitation in our opinion and as it is the fact that we have chosen the three models (Jones, Dechow and Kasznik) based on subjective reasons.

For our further developments we want to determine earnings management magnitude by calculating the discretionary accruals and analyzing their evolution by applying the modified Jones model on a more relevant sample of Romanian companies (taking into account all companies listed on Bucharest Stock Exchange and Rasdaq) divided into groups based on specific parameters.

On our future research we want to test a new Hypothesis: The companies with positive income and negative operational cash flow are manipulating their accounts.

\section{Acknowledgements}

${ }^{(*)}$ CNMP Acknowledgements This work was supported by CNMP, project number 92$085 / 2008$. The project is entitled "Developing a functional model for optimizing the national strategy regarding financial reporting within Romanian private sector entities".

${ }^{(* *)}$ Investing in people! PhD scholarship, Project co-financed by the European Social Fund, SECTORAL OPERATIONAL PROGRAMME HUMAN RESOURCES DEVELOPMENT 2007 - 2013, Babeş-Bolyai University, Cluj-Napoca, Romania

\section{References}

1. Amat, O., Perramon, J., Oliveras, E., 2003. Earnings management in Spain: some evidence from companies quoted in the Spanish stock market, available on-line at www.ssrn.com

2. Attar A.A., Hussain S., 2004. Corporate Data and Future Cash Flows. Journal of Business Finance and Accounting 31(7, 8), pp. 861-903.

3. Ball, R., Shivakumar, L., 2004. Earnings quality in U.K. private firms, Working Paper, University of Chicago and London Business School.

4. Ball, R., Kothari, S. P., Robin, A., 2000. The effect of international institutional factors on properties of accounting earnings. Journal of Accounting and Economics 29, pp. 1-51.

5. Bartov, E., Gul F. A., Tsui J., 2000. Discretionary accrual models and audit qualification. Journal of Accounting and Economics 30, pp. 421-452.

6. Bernard,V.L., Skinner D.J., 1996. What motivate manager's choice of Discretionary accrual? Journal of Accounting and Economics 22 (1/3), pp. 312-325.

7. Beatty, A.L., Harris, D.G., 1998. The effects of taxes, agency costs and information asymmetry on earnings management, Review of Accounting Studies 4, pp. 299-326.

8. Becker, C., DeFond M., Jiambalvo J., Subramanyam K. R., 1998. The Effect of Audit Quality on Earnings Management, Contemporary Accounting Research 15 (1), pp. 1-24.

9. Bowen, R., DuCharme, L., Shores, D., 1995. Stakeholders' implicit claims and accounting method choice, Journal of Accounting and Economics 20, pp. 255-295.

10. Burgstahler, D., Dichev, I., 1997. Earnings management to avoid earnings decreases and losses. Journal of Accounting and Economics 24 (1), pp. 99 - 126.

11. Burgstahle, D., Eames, M., 1998 „Management of earnings and analysts' forecasts, Working paper, University of Washington.

12. Burgstahler, D., Eames, M., 2003. Earnings management to avoid losses and earnings decreases: Are analysts fooled? Contemporary Accounting Research 20, pp. 253-276.

13. Cahan, S., 1992. The effect of anti-trust investigation on discretionary accruals: A refined test of the political cost hypothesis. The Accounting Review 67, pp. 77-95. 
14. Cheng, A., Yang, S., 2003. The Incremental Information Content of Earnings and Cash Flows from Operations Affected by Their Extremity. Journal of Business Finance and Accounting $30(1,2)$, pp. 72-116.

15. Clikeman, P.M., Geiger, M. A., O`Connell, B.T., 2001. Student Perceptions on Earnings Management: The Effects of National Origin and Gender. Teaching Business Ethics 5, pp. 389-410.

16. Collingwood, I., 1991. The earnings game. Harvard Business Review, pp. 65-74.

17. Collins, D.W., Hribar, P., 2000a. Earnings-based and accruals-based market anomalies: One effect or two? Journal of Accounting and Economics 29, pp. 101-123.

18. Courtis, J.K., 2004. Corporate report obfuscation: Artefact or phenomenon? British Accounting Review 36 (3), pp. 291-312.

19. DeAngelo, E., DeAngelo, H., Skinner, D., 1994. Accounting choices of troubled companies. Journal of Accounting and Economics 17, pp. 113-143.

20. Dechow, P. 1994. Accounting earnings and cash flows as measures of firm performance: the role of accounting accruals. Journal of Accounting and Economics 18 (1), pp. 3-42.

21. Dechow, P., Sloan R., Sweeney, A., 1995. Detecting earnings management. The Accounting Review, 70, pp. 193-225.

22. Dechow, P.M., Skinner, D.J., 2000. Earnings management: Reconciling the views of accounting academics, practitioners and regulators. Accounting Horizons 14, pp. 235-250.

23. DeFond, M.L., Jiambalvo J., 1993. Factors Related to Auditor-Client Disagreements over income-increasing accounting methods. Contemporary Accounting Research, pp. 415-431

24. DeFond, M.L., Subramanyam, K.R., 1998. Auditor changes and discretionary accruals. Journal of Accounting and Economics 25 (1), pp. 35-67.

25. Degeorge, F., Patel J., Zeckhauser R., 1999. Earnings management to exceed thresholds. Journal of Business 72, pp. 1-33.

26. Erickson, M., Wang, S., 1999. Earnings management by acquiring firms in stock for stock mergers. Journal of Accounting and Economics 27, pp. 149-176.

27. Fernandez P., 2008. Cash Flow is a Fact. Net income is just an opinion, Working Paper Series.

28. Guay, W.R., Kothari, S.P., Watts, R.L., 1996. A market-based evaluation of discretionary accrual models. Journal of Accounting and Economics 34, pp. 83-105.

29. Healy, P., 1985. The effect of bonus schemes on accounting-based dividend covenants. Journal of Accounting and Economics 7, pp. 85-107.

30. Healy, P., Palepu, K.G., 1990. Effectiveness of accounting-based dividend covenants. Journal of Accounting and Economics 12, pp. 97-124.

31. Healy, P.M., Wahlen, J.M., 1999. A review of the earnings management literature and its implications for standard setting. Accounting Horizons 13, pp. 365-383.

32. Herrmann, D., Inoue, T., 1996. Income smoothing and incentives by operating condition: An empirical test using depreciation changes in Japan. Journal of International Accounting Auditing and Taxation 5, pp. 161-177.

33. Holthausen, R., Larker, D., Sloan, R., 1995. Annual bonus schemes and the manipulation of earnings. Journal of Accounting and Economics 19, pp. $29-74$.

34. Hribar, P., Collins D., 2000. Errors in estimating accruals: Implications for Empirical Research. Journal of Accounting Research 40, pp. 105-134.

35. Jones, J.J., 1991. Earnings management during import relief investigations. Journal of Accounting Research 29, pp. 193-228.

36. Kang, S.H., Sivaramakrishanan, K., 1995. Issues in Testing earnings Management and an Instrumental variable approach. Journal of accounting Research, 33 (2), pp. 353-367.

37. Klassen, K.J., 1997. The impact of insider ownership concentration on the trade-off between financial and tax reporting. Accounting Review 72, pp. 455-474. 
38. Kirschenheiter, M., Melumad N.D., 2002. Can "big bath" and earnings smoothing co-exist as equilibrium financial reporting strategies? Journal of Accounting Research 40, pp. 761796.

39. Kothari, S.P., Leone, A., Wasley C., 2001. Performance matched discretionary accrual measures, Working paper, Massachusetts Institute of Technology.

40. Kothari, S.P., Leone A.J., Wasley C.E., 2005. Performance Matched Discretionary Accrual Measures. Journal of Accounting Economics, 39, pp. 163-197.

41. Lamb, M., Nobes, C., Roberts, A., 1998. International variations in the connections between tax and financial reporting, Accounting and Business Research, 28, pp. 173-188.

42. Larker, D.F., Richardson, S.A., 2004. Fees paid to audit firms, accruals choices, and corporate governance. Journal of Accounting Research 42, pp. 625-658.

43. McNichols, M., Wilson, G.P., 1988. Evidence of Evidence of Earnings Management from the provision for bad debts. Journal of Accounting Research 26 (Supplement), pp. 1-31.

44. Mulford, C.W, Comiskey E.E., 2003. Creative Cash Flow Reporting - uncovering sustainable financial performance. John Wiley \& Sons, Inc., pp. 37.

45. Peasnell, K.V., Pope, P.F., Young, S., 1998. Detecting earnings management using cross sectional abnormal accruals models. Accounting and Business Research, 30 (4), pp. 313 326.

46. Reider, R., Heyler, P.B., 2003. Managing Cash Flow - An Operational Focus. John Wiley \& Sons, Inc.

47. Rutherford, B.A., 2003. Obfuscation, textual complexity and the role of regulated narrative accounting disclosure in corporate governance. Journal of Management and Governance 7, pp. 187-210.

48. Schilit, H., 2002. How to Detect Accounting Gimmicks and Fraud in Financial Reports. R.R. Donnelley \& Sons Company.

49. Schipper, K., 1989. Commentary on Earnings Management, Accounting Horizons 3, pp. 91 102.

50. Sharma D., Iselin E., 2003. The Relative Relevance of Cash Flow and Accrual Information for Solvency Assessment: A Multi-Method Approach. Journal of Business Finance and Accounting $30(7,8)$, pp 1115-1140.

51. Sharma, D., 2003. Predicting Corporate Failure: When Cash Flow is King. Journal of Banking and Financial Services 23, pp. 81-115.

52. Shivakumar, L., 2000. Do firms mislead investors by overstating earnings before seasoned equity offering? Journal of Accounting and Economics 29, pp. 339-371

53. Sloan, R., 1996. Do stock prices fully reflect information in accruals and cash flows about future earnings? The Accounting Review, pp. 289-316.

54. Subramanyam, K.R., 1996. The pricing of discretionary accruals. Journal of Accounting and Economics 5, pp. 359-365.

55. Teoh, S.H., Welch, I., Wong, T.J., 1998. Earnings management and the post-issue performance of seasoned equity offerings. Journal of Financial Economics 50, pp. 63-99.

56. Young, M.R., 2000. Accounting Irregularities and Financial Fraud: A Corporate Governance Guide, pp. 13.

57. Zhang, W., 2008. Real Activities Manipulation to Meet Analysts' Cash Flow Forecasts, Working Paper Series. 